\title{
Pola Kemampuan Berpikir Kritis Matematis Berdasarkan Kecerdasan Multiple Intelligences
}

\author{
Mujib $^{\left.1^{*}\right)}$, Sukestiyarno ${ }^{2}$, Hardi Suyetno ${ }^{3}$, \& Iwan Junaidi ${ }^{4}$ \\ ${ }^{1}$ Universitas Islam Negeri Raden Intan Lampung, Bandar Lampung, Indonesia \\ ${ }_{2,3,4}$ Universitas Negeri Semarang, Semarang, Indonesia
}

\section{INFO ARTICLES}

\section{Article History:}

Received: 16-02-2021

Revised: 17-06-2021

Approved: 24-06-2021

Publish Online: 30-06-2021

Key Words:

Mathematical Critical Thinking; Multiple Intelligence; Mindset;

under a Creative Commons AttributionShareAlike 4.0 International License.

\begin{abstract}
Mathematical thinking is important in school learning, this includes the HOT and LOT levels. The purpose of this study is to describe the characteristics of the mathematical critical thinking ability pattern based on multiple intelligences combined with Ennis and Gardner's theory. This research is qualitative research. This research was conducted at SMPN 29 Bandar Lampung, with the sampling technique used was purposive sampling. The subjects of this study were 5 people. The research instrument used a mathematical critical thinking essay test, multiple intelligence questionnaire using a psychology expert, and interviews to extract data. Data analysis techniques use data reduction, data display, and drawing conclusions and verification (conclusion drawing and verification). The results showed that students were able to identify the steps in mathematical critical thinking skills. Furthermore, the students more critical in problem-solving and looks right at working on the problem. Students direct answers starting from specific things than in general. Mathematical critical thinking patterns tend to be inductive patterns.
\end{abstract}

\begin{abstract}
Abstrak: Berpikir matematis penting dalam pembelajaran di sekolah, hal ini meliputi level HOT dan LOT. Tujuan penelitian untuk mendeskripsikan karakterisitik pola kemampuan berpikir kritis matematis berdasarkan kecerdasan multiple intelligences berpaduan teori Ennis dan Gardner. Penelitian ini merupakan penelitian kualitatif. Penelitian ini dilakukan di SMPN 29 Bandar Lampung, dengan teknik sampling yang digunakan adalah purposive sampling. Subjek penelitian ini sebanyak 5 orang. Instrumen penelitian menggunakan tes essay berpikir kritis matematis, angket multiple intelligence dengan menggunakan pakar psychology, dan wawancara untuk menggali data. Teknik analisis data menggunakan reduksi data (data reduction), penyajian data (data display), dan mengambil simpulan dan verifikasi (conclusion drawing and verification). Hasil penelitian menunjukkan bahwa siswa dapat mengidentisikasi langkah pengerjaan soal kemampuan berpikir kritis matematis. Sehingga lebih kritis dalam menyelesaikan masalah, dan terlihat benar dalam pengerjaan soalnya. Siswa mengarahkan jawaban dimulai dari hal yang bersifat khusus kemudian secara umum. Pola berpikir kritis matematis cenderung dengan pola induktif.
\end{abstract}

Correspondence Address: Jl. Letkol H. Endro Suratmin Sukarame, Bandar Lampung, Lampung, Indonesia; $e$-mail: mujib@radenintan.ac.id

How to Cite (APA 6 ${ }^{\text {th }}$ Style): Mujib, M., dkk. (2021). Pola Kemampuan Berpikir Kritis Matematis Berdasarkan Kecerdasan Multiple Intelligences. JKPM (Jurnal Kajian Pendidikan Matematika), 6(2): 227-242.

Copyright: 2021 Mujib Mujib, Sukestiyarno Sukestiyarno, Hardi Suyetno, Iwan Junaidi

Competing Interests Disclosures: The authors declare that they have no significant competing financial, professional or personal interests that might have influenced the performance or presentation of the work described in this manuscript. 


\section{PENDAHULUAN}

Era industri 4.0 memegang peranan penting dalam mengembangkan kemampun berpikir kritis. Sehingga diperlukan upaya dalam meningkatkannya. Oleh karena itu, pentingnya proses berpikir kritis dalam matematika adalah sebagai berikut: (1) dapat mengembangkan keterampilan kognitif secara umum, (2) mendorong kreativitas siswa, (3) bagian dari proses aplikasi matematika, dan (4) dapat memotivasi siswa untuk belajar matematika. Dalam berpikir kritis matematis diperlukan keterampilan-keterampilan yang harus dimiliki, antara lain: (1) keterampilan empiris yang terdiri dari perhitungan dan pengukuran, (2) keterampilan aplikatif untuk menghadapi situasi yang umum (sering terjadi), serta (3) keterampilan berpikir untuk bekerja pada suatu situasi yang tidak biasa(Hamidah \& Suherman, 2016; Mujib \& Mardiyah, 2017; Sulistiani \& Masrukan, 2017).

Kemampuan berpikir kritis matematis menekankan pada siswa perlunya bernalar, merencanakan strategi berbagai dari sumber, banyak gagasan, membandingkan dengan teori terdahulu, mengkonstruksi gagasan dan membuat kesimpulan (Barnhart \& van Es, 2015; Matondang et. al., 2020; Mujib, 2019; Nugraha et. al., 2017). Pada masa transisi dari jenjang sekolah dasar ke sekolah menengah, siswa mulai dapat dilatih untuk berpikir hipotesis, proporsional, evaluatif, analitis, sintesis, kritis dan logis serta mampu memahami konsep secara abstrak (Fuad et. al., 2017; Hand et. al., 2018; Mahanal et. al., 2019). Jika dilihat dari perkembangan tersebut siswa SMP sudah mulai mampu untuk diajak berpikir ketingkat penalaran yang lebih tinggi yaitu Higher Order Thinking, bukan hanya ditingkat berpikir Lower Order Thinking. Alangkah baiknya bila pembelajaran yang dilaksanakan di SMP disesuaikan dengan taraf berpikirnya pada anak yaitu: Higher Order Thinkig, Middle Order Thinking, dan Lower Order Thinking.

Proses berpikir kritis matematis berdasarkan perpaduan teori Ennis dan Gardner memiliki 5 langkah indikator, yaitu; Elementary clarification, The basis for the decision, Inference, Advanced clarification, Supposition and integration. Data berdasarkan hasil pra-penelitian, observasi, wawancara dengan siswa dan melalui hasil tes menunjukkan bahwa: ada 3 siswa yang mencapai $(8,82 \%)$ berada pada kategori Higher Order Thinking (HOT), ada 10 siswa mencapai $(29,4 \%)$ berada pada kategori Middle Order Thinking (MOT) dan, 21 siswa mencapai $(61,7 \%)$ berada pada kategori Lower Order Thinking (LOT). Dari data pra-penelitian tersebut, tingkat kemampuan berpikir kritis matematis siswa SMPN 29 Bandar lampung cendrung pada katagori Lower Order Thinking. Selain itu di SMPN 29 Bandar Lampung guru belum melevelkan tingkat kemampuan berpikir kritis matematis. Kemampuan berpikir kritis matematis berdasarkan teori Ennis berpaduan teori Gardner kecerdasan MI (Multiple Intelligences) belum dicoba.

Kemampuan siswa menggunakan kecerdasan Multiple Intelligences, tentunya siswa akan memiliki keaktifan, kecermatan, mengingat, dan pemahaman keterampilan yang akan membantunya dalam menyelesaikan pemecahan masalah matematika yang berhubungan dengan kehidupan sehari-hari (Sitorus, 2016; Zubaidah et. al., 2017). Berdasarkan perkembangan kognitif siswa SMP yang mulai menginjak tahap berpikir tingkat tinggi, peneliti tertarik melihat pola-pola dan perpaduan kemampuan berpikir matematis teori Ennis dan Gardner dalam kecerdasan Multiple Intelligences terhadap perkembangan kemampuan kognitif siswa SMPN 29 Bandar Lampung. Kecerdasan MI yang lebih mengedepankan kemampuan keterampilan metakognitif dan kemampuan berpikir kritis matematis, yang tercermin dalam diri siswa. Setiap siswa memiliki kecerdasan Multiple Intelligences yang berbeda-beda. Kecerdasan yang dimiliki siswa untuk melihat langkah-langkah dalam proses kemampuan berpikir kritis matematis.

Berdasarkan hal tersebut, menunjukkan bahwa siswa memiliki kemampuan berpikir kritis matematis dalam belajar matematika dengan tiga hal yang dilakukan. Tahap pertama siswa perlu dibimbing secara bersama-sama dengan cara pemberian tugas mandiri, tugas per kelompok, diskusi secara bersama-sama terutama dalam melakukan langkah kegiatan proses pembelajaran, siswa yang mempunyai kemampuan berpikir kritis matematis pada kategori Lower Order Thinking karena hal ini merupakan kesulitan yang 
dialami oleh semua siswa. Tahap kedua adalah siswa masih perlu pendampingan dalam pemberian tugas mandiri, pemberian tugas antar kelompok, diskusi dan tanya jawab dalam proses pembelajaran terutama pada kategori MOT. Akan tetapi pada tahap ketiga bagi siswayang berkemampuan HOT tidak perlu dilakukan pendampingan dalam pemberian tugas mandiri, tugas kelompok, diskusi kelompok baik secara individual. Oleh karena itu dengan mengetahui pada tahap mana siswa mengalami kesulitan, maka guru dalam proses pembelajaranakan dapat memilih yang sesuai dengan kebutuhan siswa melalui proses pembelajaran (scaffolding). Pendampingan yang membawa siswa mencapai tujuan kognitif sangat dibutuhkan mereka (Anisa, 2017). Hal ini juga berlaku untuk siswa yang lainnya. Peneliti tertarik membuat Kecerdasan Multiple Intelligences berpaduan Teori Ennis dan Gardner.

Berdasarkan penelitian terdahulu bahwa siswa dengan kecerdasan multiple intelligences memiliki kemampuan yang berbeda-beda dalam pembelajaran (Sener \& Çokçaliskan, 2018). Penelitian membahas tentang karakteristik siswa dalam tinjauan multiple intelligences dan gender. Penelitian ini memiliki kekurangan bahwa hanya terbatas pada jenis kecerdasan dan gaya belajar berkorelasi positif sedang. Selain itu, penelitian lain menyebutkan bahwa kecerdasan multiple intelligences dapat dipadukan dengan teori Gadner (Glazzard, 2015). Penelitian ini berfokus pada teori-teori yang dijabarkan untuk mendukung tipe kecerdasan. Kemudian penelitian lainnya menyebutkan bahwa pelacakan multiple intelligences siswa dapat dilacak dengan menggunakan pembelajaran online (Perveen, 2018). Penelitian hanya membahas dampaknya pembelajaran online terhadap kecerdasan siswa.

Berdasarkan penelitian di atas, maka penelitian ini memiliki kebaruan bahwa pengukuran pola kecerdasan multiple intelligences berpaduan pada teori Ennis dan Gardner untuk melihat kemampuan berpikir kritis matematis. Oleh karena itu, penelitian ini bertujuan untuk mendeskripsikan karakterisitik pola kemampuan berpikir kritis matematis berdasarkan kecerdasan multiple intelligences berpaduan teori Ennis dan Gardner.

\section{METODE}

Penelitian ini merupakan penelitian kualitatif. Pengambilan subjek dilakukan berasal dari siswa kelas VII SMPN 29 Bandar Lampung tahun ajaran 2019/2020. Subjek penelitian ini diambil dari 32 siswa kelas VII yang telah dilakukan tes psikologi. Subjek diambil sebanyak 5 siswa dengan teknik pengambilan sampling menggunakan purposive sampling. Hal ini didasarkan pada purposive sampling dengan 5 kategori siswa yang mewakili kecerdasan Multiple Intelligences dan mampu memberikan jawaban atas tes dan pertanyaan yang diajukan. Tes digunakan untuk mengukur tingkat kemampuan berpikir kritis matematis siswa berdasarkan kecerdasan Multiple Intelligences. Angket disusun untuk melihat kecendrungan kecerdasan Multiple intlligences yang bersifat tertutup, menggunakan pakar psychology. Teknik analisis data menggunakan pola Huberman dan Miles dengan siklus terlihat pada Gambar 1. (Miles et. al., 2018).

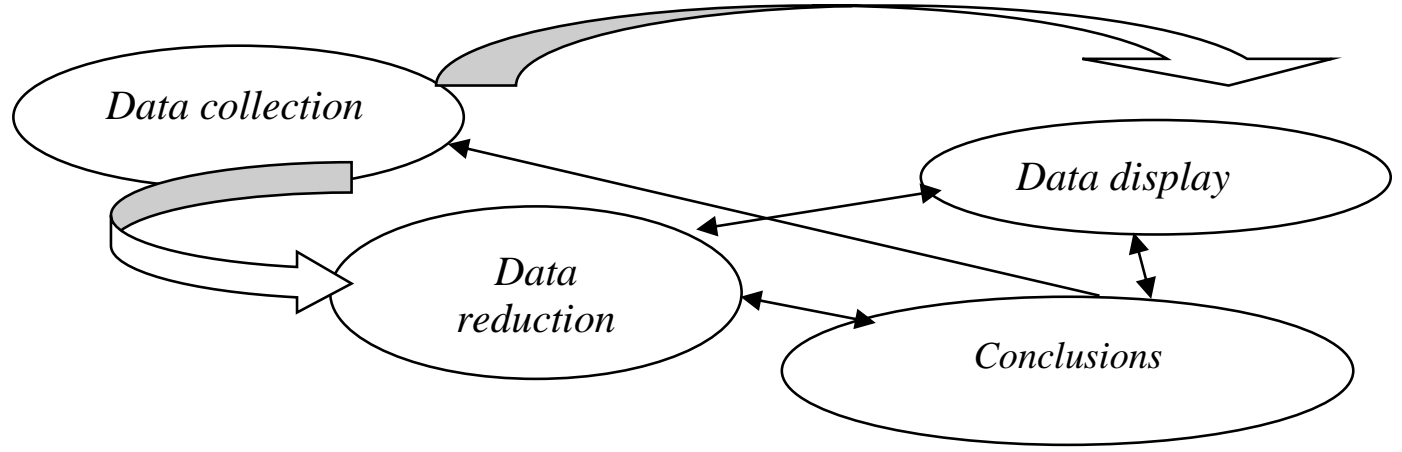

Gambar 1. Komponen-Komponen Analisa Data Model Interaktif 
Adapun indikator dalam multiple intelligences sebagaimana terlihat dalam Tabel 1.

Tabel 1. Indikator Kecerdasan Multiple Intelligences

\begin{tabular}{|c|c|c|}
\hline No & Tahapan & $\begin{array}{c}\text { Indikator Kecerdasan Muliple } \\
\text { Intelligences }\end{array}$ \\
\hline 1 & $\begin{array}{l}\text { Linguistik } \\
\text { (Linguistic } \\
\text { Intelligences) }\end{array}$ & $\begin{array}{l}\text { Memahami aturan tata Bahasa, } \\
\text { Mampu mengolah kata. Menulis dan } \\
\text { menjelaskan. }\end{array}$ \\
\hline 2 & $\begin{array}{l}\text { Matemati-Logis } \\
\text { (Logical } \\
\text { Mathematical } \\
\text { Intelligences) }\end{array}$ & $\begin{array}{l}\text { Unggul dalam matematika. Suka } \\
\text { menganalisis. Berpikir dengan angka. } \\
\text { Berhitung. Menarik kesimpulan. }\end{array}$ \\
\hline 3 & $\begin{array}{l}\text { Kecerdasan Ruang } \\
\text { (spatial } \\
\text { intelligence) }\end{array}$ & $\begin{array}{l}\text { Suka mengambar. Mudah } \\
\text { membayangkan sebuah benda dilihat } \\
\text { dari berbagai sudut. Mengamati dan } \\
\text { memahami bentuk tiga demensi. Suka } \\
\text { mencorat-coret bila sedang bertelepon. }\end{array}$ \\
\hline 4 & $\begin{array}{l}\text { Kinestetik- badani } \\
\text { (bodily- } \\
\text { kinesthetic } \\
\text { intelligence) }\end{array}$ & $\begin{array}{l}\text { Suka berolah raga. Tidak betah duduk } \\
\text { diam dalam waktu yang lama. Ketika } \\
\text { berpikir biasanya harus bergerak. } \\
\text { Menyukai kegiatan yang } \\
\text { membutuhkan ketrampilan tangan. }\end{array}$ \\
\hline 5 & $\begin{array}{l}\text { Musikal (Musical } \\
\text { intelligence) }\end{array}$ & $\begin{array}{l}\text { Mudah menghafal nada lagu yang baru } \\
\text { didengar. Suka bekerja sambil } \\
\text { beryanyi. Mengenal berbagai jenis } \\
\text { irama musik. Sangat berminat untuk } \\
\text { mengetahui perkembangan musik. }\end{array}$ \\
\hline 6 & $\begin{array}{l}\text { Interpersonal } \\
\text { (interpersonal } \\
\text { intelligence) }\end{array}$ & $\begin{array}{l}\text { Mudah berteman. Suka bekerja dalam } \\
\text { kelompok. Suka kegiatan sosial. } \\
\text { Banyak berbicara. Suka memotivasi } \\
\text { orang lain. Bisa mengatur atau } \\
\text { memimpin. Sekelompok orang. }\end{array}$ \\
\hline 7 & $\begin{array}{l}\text { Intrapersonal } \\
\text { (Intrapersonal } \\
\text { intelligence) }\end{array}$ & $\begin{array}{l}\text { Suka bekerja seorang diri. Mampu } \\
\text { bekerja secara mandiri. Mampu } \\
\text { mengungkapkan dan menyalurkan } \\
\text { perasan dan pikiran. Sering } \\
\text { mengintrospeksi diri. }\end{array}$ \\
\hline
\end{tabular}

Kemampuan

untuk mengembangkan,

mengekspresikan, dan menikmati bentuk-bentuk musik dan suara, peka terhadap irama, melodi, dan intonasi serta kemampuan memainkan alat musik .

Kemampuan untuk mengerti dan menjadi peka terhadap perasaan, intensi, motivasi, watak, temperamen orang lain. Kemampuan yang menonjol dalam berelasi dan berkomunikasi dengan orang.

Kemampuan yang berkaitan dengan pengetahuan akan diri sendiri dan kemampuan untuk bertindak secara adaptif berdasar pengalaman diri serta mampu berefleksi dan keseimbangan diri, kesadaran tinggi akan gagasangagasan. 


\begin{tabular}{|c|c|c|c|}
\hline No & Tahapan & $\begin{array}{c}\text { Indikator Kecerdasan Muliple } \\
\text { Intelligences }\end{array}$ & $\begin{array}{l}\text { Sub Indikator Muliple } \\
\text { Intelligences }\end{array}$ \\
\hline 8 & $\begin{array}{l}\text { Naturalis } \\
\text { (Naturalist } \\
\text { intelligence) }\end{array}$ & $\begin{array}{l}\text { Suka bepergian atau hiking (naik } \\
\text { gunung). Suka mengamati, mengenali, } \\
\text { berintraksi. Senang memelihara } \\
\text { tanaman dan hewan. Perduli dengan } \\
\text { lingkungan hidup. }\end{array}$ & $\begin{array}{l}\text { Mereka mudah berkonsentrasi } \\
\text { dengan baik, suka bekerja sendiri } \\
\text { dan cenderung pendiam. } \\
\text { Kemampuan untuk mengerti flora } \\
\text { dan fauna dengan baik, menikmati } \\
\text { alam, mengenal tanaman dan } \\
\text { binatang dengan baik. }\end{array}$ \\
\hline
\end{tabular}

Sumber: (Setiawan \& Mardapi, 2020)

Sedangkan pola kemampuan berpikir kritis matematis yang digunakan adalah tingkat 4 (Sangat Kritis) yaitu siswa mampu mengidentifikasi masalah, menjelaskan, menggunakan bukti-bukti yang benar, menarik kesimpulan, member penjelasan lanjut, dan mampu memadukan membuat suatu keputusan dalam pemecahan masalah matematika. Tingkat 3 (Kritis) yaitu siswa mampu mengidentifikasi masalah, menjelaskan, menggunakan bukti-bukti yang benar, menarik kesimpulan, memberi penjelasan lanjut dan kurang mampu memadukan membuat suatu keputusan dalam pemecahan masalah matematika. Tingkat 2 (Cukup Kritis) yaitu siswa mampu mengidentifikasi masalah, menjelaskan, menggunakan bukti-bukti yang benar, menarik suatu kesimpulan, belum mampu memberi penjelasan dan belum mampu memadukan membuat suatu keputusan dalam pemecahan masalah matematika. Tingkat 1 (Kurang Kritis) yaitu siswa mampu mengidentifikasi masalah, menjelaskan, belum menggunakan bukti-bukti yang benar, belum mampu menarik kesimpulan, belum mampu memberi penjelasan lanjut, dan tidak mampu memadukan membuat suatu keputusan dalam pemecahan masalah matematika. Tingkat 0 (Tidak Kritis) yaitu siswa tidak mampu mengidentifikasi masalah, memberi penjelasan, menggunakan bukti-bukti yang benar, menarik suatu kesimpulan, dan tidak mampu memadukan membuat suatu keputusan dalam pemecahan masalah matematika (Mujib, 2019). Triangulasi yang digunakan menggunakan triangulasi sumber.

\section{HASIL}

Hasil penelitian terhadap penggolongan tipe kecerdasan siswa di SMPN 29 Bandar Lampung terlihat pada Gambar 2. Berdasarkan Gambar 2., dapat diketahui bahwa penggolongan kecerdasan yang dimiliki oleh siswa meliputi kecerdasan linguistic, Bodily kinethetic thetic, Interpersonal, Musical, Interpersonal, Logical-Mathematical, Spacial. Selain itu terdapat hubungan antara kecerdasan tersebut dengan kecerdasan interpersonal, musical, linguistic, dan kinethetic thetic. 


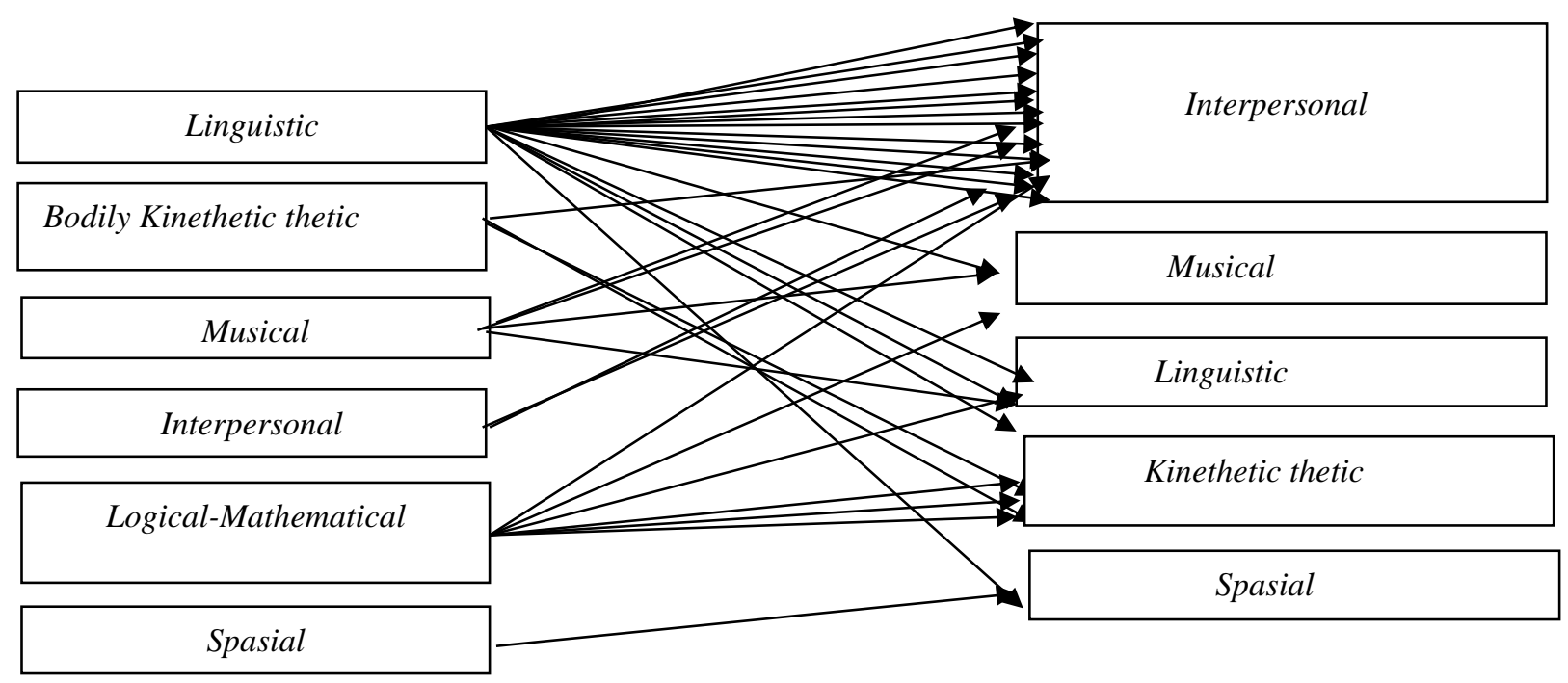

Gambar 2. Taraf Kecerdasan yang Dimiliki Siswa

Adapun jumlah banyaknya siswa dengan hubungan tersebut dapat dilihat dalam Tabel 2.

Tabel 2. Hasil Penggolongan Kecerdasan Umum Kelas VII.11 SMPN 29 Bandar Lampung

\begin{tabular}{clcc}
\hline No & Taraf Kecerdasan & Banyak Siswa (Orang) & Skor \\
\hline 1 & Tinggi Sekali & 3 & $122-140$ \\
2 & Tinggi & 7 & $111-115$ \\
3 & Cukup & 11 & $100-109$ \\
4 & Sedang & 8 & $92-98$ \\
5 & Rendah & 3 & $86-89$ \\
& Jumlah Siswa & 32 & \\
\hline
\end{tabular}

Sumber: diolah dari data penelitian, 2020

Berikut deskripsi karakteristik pola kemampuan berpikir kritis matematis salah satu siswa berdasarkan kecerdasan multiple intelligences berpaduan teori Ennis dan Gardner. Data tertulis ASD pada Multiple Intelligences tinggi sekali untuk soal berpikir kritis matematis.

Subjek ASD melaksanakan Multiple Intelligences dalam pemecahan masalah. Berikut data hasil testertulis dan wawancara terhadap subjek ASD tahap Multiple Intelligences. Adapun deskripsi wawancara sebagai berikut:

PE : "Ok...Berdasarkan soal yang telah dikerjakan... bagaimanakah bentuk soal tes yang telah kamu kerjakan? Dan apa saja yang kamu ketahui dari soal nomor satu?" ( Peneliti bertaya pada ASD)

ASD : "Siswa Langsung Jawab" (Bentuk soal terkait dengan penjumlahan aljabar dengan dua variable Pak).

PE : "Bagaimanakah rumus yang kamu gunakan? Jelaskan" (Peneliti kembali bertanya)

ASD : "Siswa berpikir sebentar dan menjawab" (Ada...langsung dijumlahkan seperti penjulahan $a+b$, maka akan didapat hasil sesuai dengan soal)

PE : "Selanjutnya...berdasarkan soal tersebut. Bagiamanakah kamu memperoleh informasi baru terkait masalah dalam soal tersebut?" (kembali peneliti bertanya)

ASD : "Begini Pak" (Saya memperolehnya dengan memahami infomasi dan perintah dari soal yang ada pak...)

PE : "Apakah informasi tersebut dapat digunakan untuk menjawab soal?" (Peneliti Kembali bertanya)

ASD : "Siswa berpikir dan lalu menjawab" (Iya ... bisa digunakan) 
PE : "Bagaimana kamu menemukan jawaban itu sehingga kamu yakin dengan jawabannya?" (Peneliti bertanya kembali)

ASD : "Siswa kembali berpikir dan langsung menjelaskan" (Memulainya dari memahami soal kemudian menjawab apa yang ditanyakan, runtut dari awal hingga akhir, kemudian menelaah apakah jawaban saya benar atau salah yaitu dengan mengecek kembali)

Berdasakan percakapan di atas, berikut hasil jawaban siswa ASD

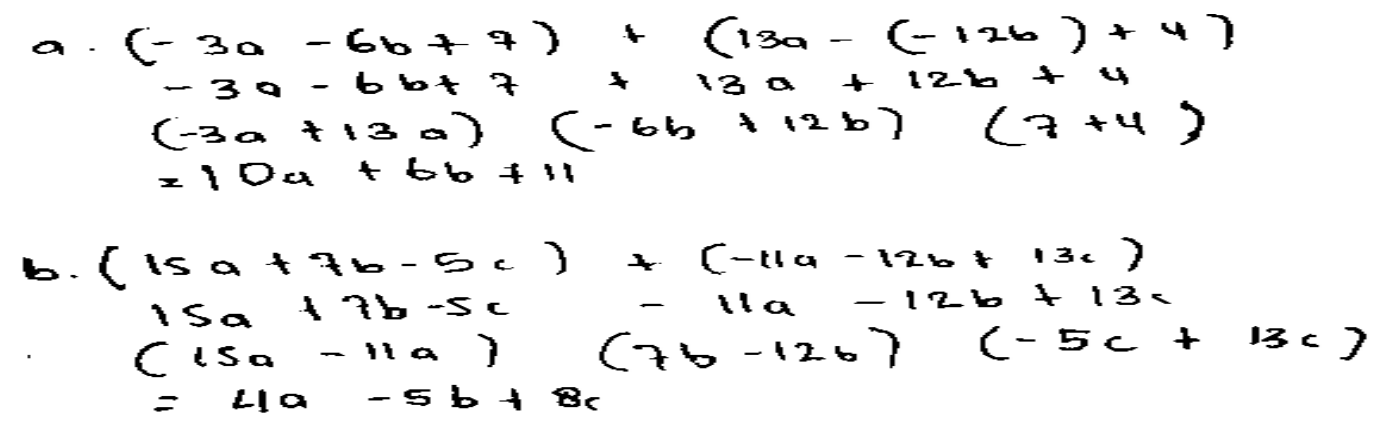

Gambar 3. Jawaban Siswa dengan Kecerdasan Interpersonal

Berdasarkan Gambar 3. bahwa siswa menjawab sesuai dengan pertanyaan soal. Kemudian menjumlahkan dua buah suku dengan 2 variabel. Terlihat siswa mengelompokkan variabel yang sama, begitu pula dengan konstannya. Siswa cenderung mengerjakan runtut dari awal hingga akhir, kemudian mengecek kembali jawabannya. Sehingga jawaban yang dihasilkan adalah benar. Subjek ASD melakukan justifikasi pada tahapan pemecahan masalah. Subjek ASD melakukan justifikasi terhadap masalah dari soal yang diungkapkan oleh subjek. Subjek ASD melakukan justifikasi terhadap informasi yang diperoleh dari soal dan rumus. Subjek ASD juga melakukan justfikasi terhadap langkah-langkah yang akan digunakan subjek untuk menjawab soal. Subjek ASD melakukan justifikasi terhadap penerapan langkah-langkah pada tahap menerapkan. Subjek ASD juga melakukan justifikasi terhadap solusi yang diperoleh. Justifikasi yang dilaksanakan subjek ASD dalam pemecahan masalah yang pertama dilakukan secara rasional karena lebih menggunakan logika dari pada trial and error atau informasi dalam persepsi semata. Ini dapat diketahui dengan mengindentifikasi percakapan peneliti dengan siswa pada penerapan langkah yang digunakan dalam memecahkan masalah.

Subjek NR melaksanakan Multiple Intelligences dalam pemecahan masalah. Berikut data hasil tes tertulis dan wawancara terhadap subjek NR tahap Multiple Intelligences.

1PE1 : :Kamu sudah membaca soal dan telah mengerjakannya...?.

Informasi apa saja yang dapat diperoleh dari soal nomor satu?" (Peneliti bertanya tentang memahami, dan informasi apa yang didapat dalam soal).

1NR1 : :Siswa menjawab dengan singkat" (Informasi terkait dengan bentuk aljabar pak...)

1PE2 : :Bagaimana kamu menyelesaikan soal tersebut? Apakah ada cara

tertentu atau rumus yang kamu gunakan? Jelaskan" (Peneliti bertanya menjawab soal, dan rumus yang digunakan).

1NR2 : "Siswa langsung menjawab" (Dengan langsung menjumlahkannya seperti penjumlahan a $+b$, maka Akan didapat hasil sesuai dengan soal).

1PE3 : Selanjutnya...berdasarkan soal tersebut. Apakah ada cara lain yang kamu kerjakan dan adakah informasi baru yang diperoleh?" (Peneliti bertanya tentang jawaban lain dan informasi apa yang didapat).

1NR3 :"Siswa menjawab dengan beriti sejenak" (Hmm...Tidak ada pak, informasinya juga hanya perintah yang ada dalam soal tersebut). 
1PE4 : "Bagaimana kamu mendapatkan informasi tambahan yang dapat digunakan untuk menjawab soal?" (Peneliti bertanya tentang informasi yang lain).

1NR4 : "Siswa mejawab dengan Ragu". (Dengan memper dalam pertanyaan dan mengulang-ulang apa yang ada dalam perintah soal pak).

1PE5

: "Bagaimana kamu meyakinkan terhadap jawabanmu yang telah

kamu peroleh? Apakah sudah benar?" (Peneliti bertanya hasil penyelesaian).

1NR5 :"Siswa menjawab dengan melihat jawaban" (Mengulangnya kembali pak, dan saya yakin sudah benar jawaban saya pak...)

Berdasakan percakapan di atas, berikut hasil jawaban subjek NR

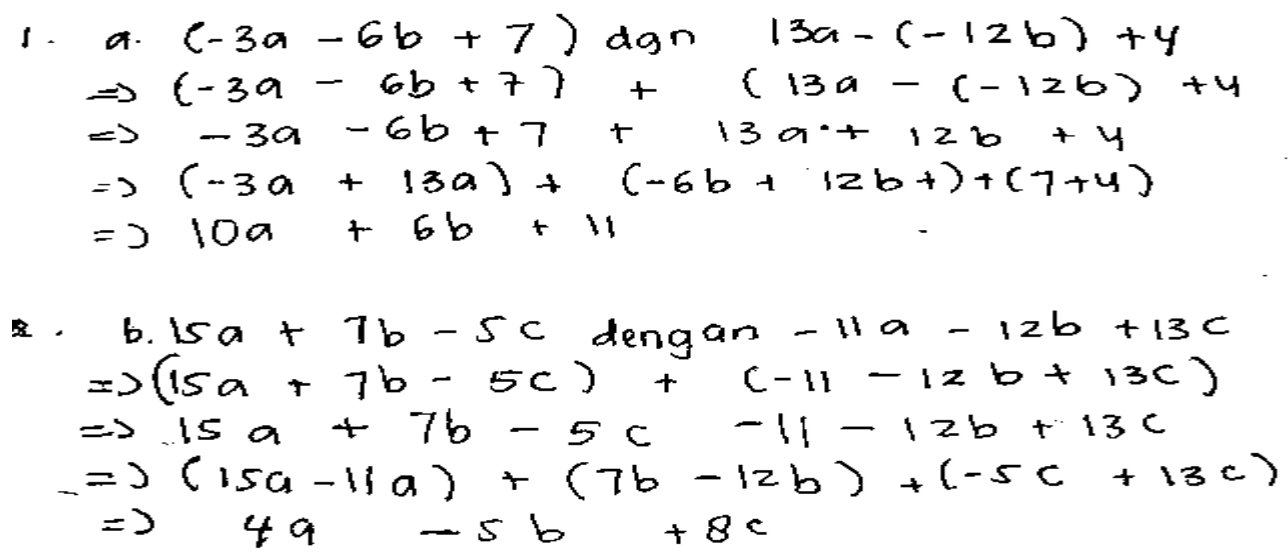

\section{Gambar 4. Jawaban Siswa dengan Kecerdasan Musical}

Berdasarkan Gambar 4., langkah-langkah yang digunakan subjek NR adalah pertama menuliskan soal yang ditanyakan. Setelah itu mengklasifikasikan suku aljabar berdasarkan soal yang didapat dengan cara memberi tanda kurung biasa. Kemudian membuka kurung biasa tersebut dengan cara seperti mengalikan simbol bilangan "negatif” dan "positif". Selanjutnya, menyatukan suku yang sejenis, yaitu suku dengan variabel $a$ dan $b$, serta konstanta. Hasil akhir dengan menjumlahkannya masing-masing. Hal tersebut juga dilakukan NR pada soal nomor $b$.

Subjek DCM melaksanakan Multiple Intelligences dalam pemecahan masalah. Berikut data hasil tes tertulis dan wawancara terhadap subjek DCM tahap Multiple Intelligences sebagai berikut:

PE

: "Baik... DCM sudah membaca soal dan mengerjakan soal yang diberikan ya...? Apa saja sih yang kamu sudah diperoleh dari soal nomor satu yang telah kamu kerjakan?" (Peneliti bertanya tentang soal).

DCM : :Siswa menjawab dengan singkat” (Soal yang diberikan adalah penjumlahan ).

PE :"Apakah ada bentuk praktis atau rumus yang akan DCM gunakan?” (Peneliti bertanya tentang rumus yang digunakan)

DCM : :Siswa menjawab dengan singkat" (Tidak ada...langsung saja kok pak dengan menjumlahkan).

PE : "Oke...Selanjutnya...berdasarkan soal tersebut. Apakah ada informasi baru yang akan di peroleh?" (Peneliti bertanya isi atau info yang didapat dalam soal).

DCM : :Siswa kembali bertanya" (Informasi apa pak? Sepertinya tidak ada informasi lagi pak... DCM sambil menerka informasi lain yang ada dalam soal).

PE : : $\quad$ :Bagaimana dengan langkah yang telah DCM gunakan?” (Peneliti kembali bertanya tentang langkah-langkahnya). 
DCM

:"Siswa menjelaskan” (Iya...begini pak langkahnya (sambil menunjukkan langkah jawabannya).

PE :"Apakah langkahmu sudah benar untuk semua soal no 1?" (Peneliti bertanya tentang langkahnya sudah cocok).

DCM :"Siswa menjawab dengan yakin" (ya pak...Saya yakin sudah benar dan tepat..)

$\mathrm{PE}$

:"Coba priksa kembali langkahnya" (Peneliti meminta ulang mengecek jawabanya DCM memeriksa langkaah pengerjaannya).

DCM :"Siswa Menunjukan dengan yakin" ( Ini pak sudah benar kok semuanya...DCM yakin terhadap hasil pengerjaannya).

Berdasakan percakapan di atas, berikut hasil jawaban subjek DCM

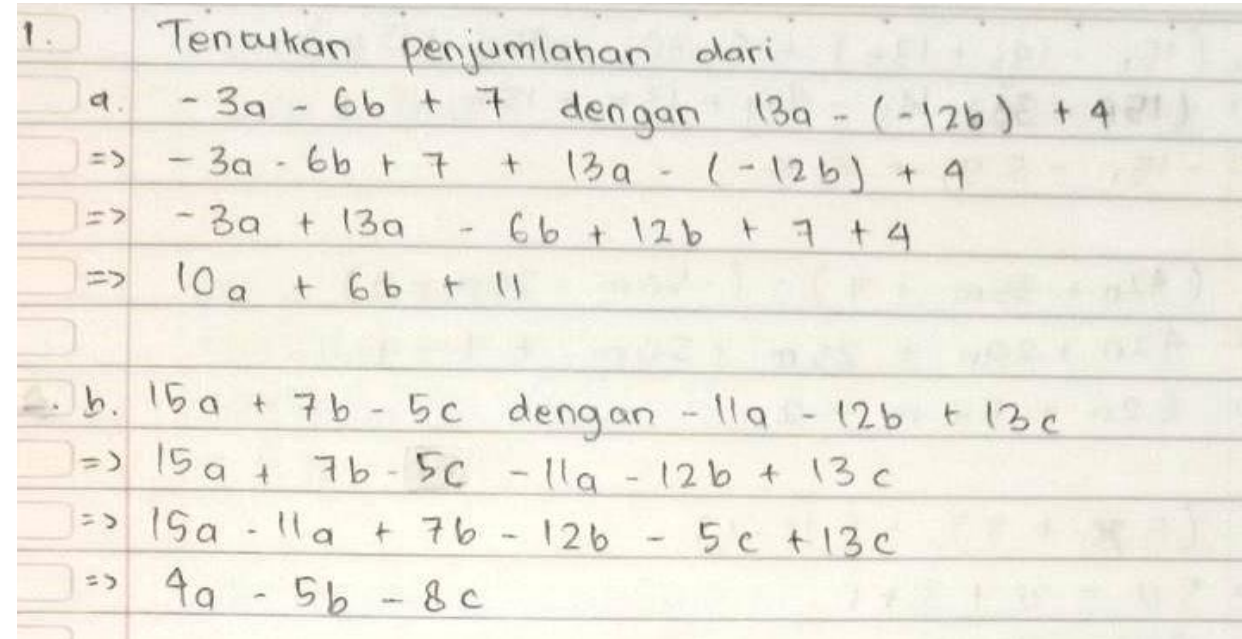

Gambar 5. Jawaban Siswa dengan Kecerdasan Linguistic

Berdasarkan Gambar 5., maka DCM menggunakan langkah-langkah yang sudah sesuai, terlihat dari hasil pengerjaan untuk nomor $1 a$ dan $1 b$.DCM meengerjakan soal dengan cara langsung tanpa menyatukan suku yang sejenis, misalkan suku dengan variabel $a$ dan $b$, serta konstanta. Hasil akhir yang dilakukan DCM adalah benar.

Subjek GA melaksanakan Multiple Intelligences dalam pemecahan masalah. Berikut data hasil tes tertulis dan wawancara terhadap subjek GA tahap Multiple Intelligences sebagai berikut:

$\mathrm{PE}$

: "Baik... GA sudah membaca soal dan mengerjakan soal yang diberikan ya...?. Bagaimana kamu mendapatkan perintah dalam soal dan apa saja sih yang sudah diperoleh dari soal nomor satu yang telah kamu kerjakan?" (Peneliti bertanya tentang cara memahami soal).

GA :"Siwa menjawab pertayaan peneliti” (Perintahnya diminta menyelesaikan bentuk penjumlahan aljabar ).

PE $\quad$ :"Apakah ada bentuk praktis atau rumus yang akan GA gunakan?” (Peneliti meminta rumus yang digukan secara praktis).

GA : "Siswa menjawab secara singkat" (Tidak ada...langsung saja kok pak dengan menjumlahkan).

PE $\quad$ : "Oke...Selanjutnya...berdasarkan soal tersebut. Apakah GA mendapatkan informasi lain?" (Peneliti bertaya tentang info yang didapat dalam soal).

GA :"Siswa terdiam sejenak dan berpikir" (Ehm...sepertinya tidak ada informasi lain pak? GA yakin bahwa tidak ada informasi tambahan dalam soal). 
PE

GA

PE

GA

PE

GA
:"Bagaimana dengan langkah yang telah GA gunakan itu?" (Peneliti bertanya tentang langkah ya digunakan).

: "Langsung menjawab dengan singkat" (Ini pak langkahnya,

GA menunjukkan langkah-langkah jawabann).

:"Apakah langkahmu sudah benar untuk semua soal no 1?" (Peneliti bertanya tentang langkahnya sudah benar).

:"Siswa menjawab dengan yakinsetahg ragu-ragu" (Iya pak...GA sudah yakin sih.... GA sedikit tidak yakin dengan jawabannya)

:"Coba priksa kembali hasilnya ya..." (peneliti meminta priksa jawabannya).

:"Siswa menjawab dengan singkat", (GA memeriksa hasil jawabannya Sepertinya saya sudah yakin sih pak dengan jawaban ini... GA yakin terhadap hasil pengerjaannya).

Berdasakan percakapan di atas, berikut hasil jawaban subjek GA

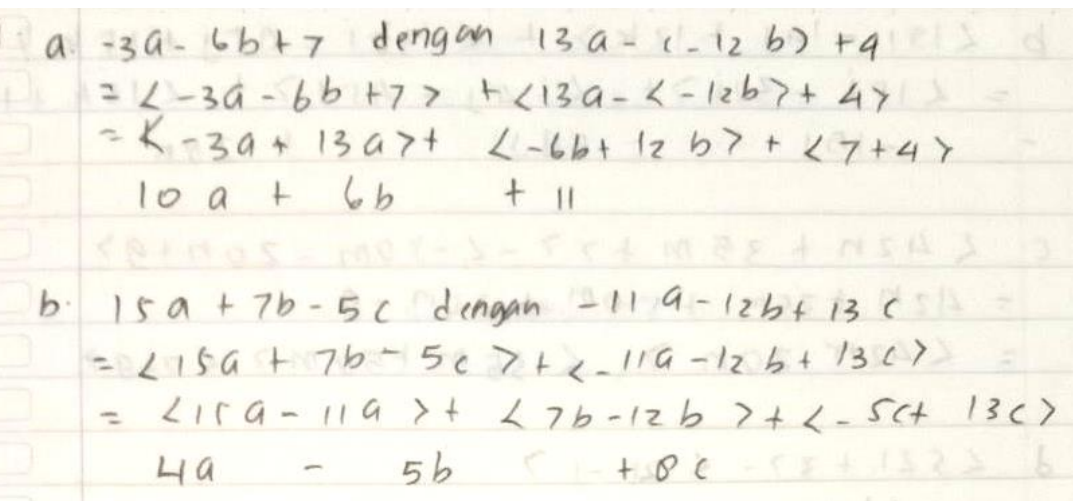

Gambar 6. Jawaban Siswa dengan Kecerdasan Kinethetic thetic

Berdasarkan Gambar 6., bahwa GA menggunakan langkah-langkah yang sesuai, terlihat dari hasil pengerjaan untuk nomor $1 a$ dan $1 b$. GA mengerjakan soal dengan cara langsung, namun GA mengerjakan dengan menyatukan variabel $a, b$, dan $c$, serta konstanta. Hasil akhir yang dilakukan GA adalah benar.

Subjek LS melaksanakan Multiple Intelligences dalam pemecahan masalah. Berikut data hasil tes tertulis dan wawancara terhadap subjek LS tahap Multiple Intelligences sebagai berikut:

PE $\quad$ :"Baik... apakah LS sudah membaca soal semuanya?” (Peneliti bertanya tentang memahami soal)

LS : :Siswa menjawab dengan singkat" (Sudah pak...)

PE : : $\quad$ :Soal tentang apa? Apakah bisa mengerjakannya?” (Peneliti bertanya tentang soal).

LS : :Siswa langsung menjawab dengan keraguan” (Tentang penjumlahan pak. Ehm ...LS merasa tidak yakin dengan peengerjaannya).

PE : : $\quad$ :Oke...Selanjutnya...berdasarkan soal tersebut. Apakah LS mendapatkan informasi terkait soal?" (Peneliti bertanya terkait dengan soal ada informasi apa).

LS :"Siswa menjawab dengan tidak ada keraguan dan singkat" (Tidak ada pak, hanya diminta menjumlahkan saja kok...LS menunjukkan jawaban soalnya)

PE : :Bagaimana dengan langkah yang telah LS gunakan ya?" (Peneliti bertanya ada kesulitan dengan langkah penyelesaian).

LS

PE :"Apakah langkahmu sudah benar untuk semua soal nomor 1?" (Peneliti bertanya tentang langkah penyelesaiaan). 
:"Siswa merasa kesulitan" (Susah pak...soalnya LS mengalami kesulitan dalam mengererjakan, terlihat dari jawaban LS).

$\mathrm{PE}$

:"Coba priksa kembali langkah-langkah dan hasilnya ya..." (Peneliti meminta memeriksa jawabanya).

:" Siswa menjawab dengan lantang”" (Susah pak...ini jawaban saya...

LS merasa kesulitan dalam bentuk operasi aljabar, LS memeriksa hasil jawabannya)

Berdasakan percakapan di atas, berikut hasil jawaban subjek LS

$$
\begin{aligned}
& \text { 1. } a \cdot 3 a+6 b-7(13 a-12 b+4)=3 a+6 b-7(13 a+2 b+4) \\
& 3 a+13 a+6 b+12-4=16 a+18-12-4 \text {. } \\
& \text { b. } 15 a+11 a+7 b+12 b-5 c-13 c=16 a+19 b=18 c \text {. }
\end{aligned}
$$

Gambar 7. Jawaban Siswa dengan Kecerdasan Spasial

Berdasarkan Gambar 7., bahwa LS menggunakan langkah-langkah yang kurang tepat, terlihat dari hasil pengerjaan untuk nomor $1 a$ dan $1 b$. Pada soal nomor $1 a$, LS menuliskan soal yang salah, yaitu soal $-3 a-6 b+7$ ditulis dengan $3 a+6 b-7$, sedangkan operasi penjumlahannya tidak dituliskan. Selanjutnya, membentuk perkalian antara konstanta 7 dengan $13 a-(-12 b)+4$ dengan bentuk $7(13 a-(-12 b)+4)$. Hal ini menyebabkan kesalahan yang didapat oleh LS. Dan hasil akhir juga mengakibatkan kesalahan, yaitu $16 a+16-12-4$.

\section{PEMBAHASAN}

Triangulasi data dilakukan untuk mengetahui valid atau tidaknya data yang diperoleh dengan cara membandingkan data dari wawancara. Hasil triangulasi data subjek ASD bahwa siswa cenderung memiliki pola berpikir kritis matematis yang sangat kritis, siswa mampu mengidentifikasi masalah, menjelaskan, menggunakan bukti-bukti yang benar, menarik kesimpulan, memberi penjelasan lanjut, dan mampu memadukan suatu keputusan dalam pemecahan masalah matematika. Siswa mengarahkan jawaban dimulai dari hal yang bersifat khusus kemudian secara umum. Pola berpikir kritis matematis cenderung dengan pola induktif.

Hasil triangulasi data subjek NR bahwa siswa cenderung memiliki pola berpikir kritis matematis yang kritis. Siswa mampu mengidentifikasi masalah, menjelaskan, menggunakan bukti-bukti yang benar, menarik kesimpulan, memberi penjelasan lanjut dan kurang mampu memadukan membuat suatu keputusan dalam pemecahan masalah matematika. Siswa mengarahkan jawaban dimulai dari hal yang bersifat khusus kemudian secara umum. Pola berpikir kritis matematis cenderung dengan pola induktif.

Selanjutnya adalah data triangulasi subjek DCM memberikan informasi bahwa siswa cenderung memiliki pola berpikir kritis matematis yang cukup kritis. Siswa mampu mengidentifikasi masalah, menjelaskan, menggunakan bukti-bukti yang benar, menarik suatu kesimpulan, belum mampu memberi penjelasan dan belum mampu memadukan membuat suatu keputusan dalam pemecahan masalah matematika. Siswa mengarahkan jawaban dimulai dari hal yang bersifat khusus kemudian secara umum. Pola berpikir kritis matematis cenderung. Subjek GA dengan hasil triangulasi adalah siswa cenderung memiliki pola berpikir kritis matematis yang kurang kritis. Siswa mampu mengidentifikasi masalah, menjelaskan, belum menggunakan bukti-bukti yang benar, belum mampu menarik kesimpulan, belum mampu memberi penjelasan lanjut, dan tidak mampu memadukan membuat suatu keputusan dalam 
pemecahan masalah matematika. Siswa mengarahkan jawaban dimulai dari hal yang bersifat umum kemudian secara khusus. Pola berpikir kritis matematis cenderung dengan pola deduktif.

Sedangkan subjek LS dengan triangulasi data bahwa siswa cenderung memiliki pola berpikir kritis matematis yang tidakkritis. Siswa tidak mampu mengidentifikasi masalah, memberi penjelasan, menggunakan bukti-bukti yang benar, menarik suatu kesimpulan dan tidak mampu memadukan dalam membuat suatu keputusan dalam pemecahan masalah matematika. Siswa mengarahkan jawaban dimulai dari hal yang bersifat umum kemudian secara khusus. Pola berpikir kritis matematis cenderung dengan pola deduktif.

Berdasarkan data di atas bahwa pada tahap elementary clarification, siswa ASD fokus pada pertanyaan yang diberikan oleh peneliti, sehingga siswa dapat mengidentifikasi pertanyaan atau masalah yang ada (Hartinah et. al., 2019; Komarudin et. al., 2020; Setyawati, 2020). Selain itu, siswa dapat mengidentifikasi jawaban yang mungkin akan didapatnya. Kemudian siswa dapat mengidentifikasi kesimpulan dari masalah yang telah diberikan. Terlihat bahwa soal yang diberikan terkait dengan penjumlahan dan pengurangan bentuk aljabar (Huda et. al., 2019; Suherman, 2013). Pada tahap basis for the decision, bahwa siswa dapat mempertimbangkan jawaban dari apa yang telah meraka pelajari sebagai materi prasyarat, yaitu penjumlahan dan pengurangan. Kemudian siswa mulai mengamati soal dan langkahlangkah yang telah dikerjakannya untuk merencanakan hasil yang didapat. Tahap Inference, siswa dapat mempertimbangkan capaian hasilnya, mempertimbangkan apakah hasil jawaban tersebut telah sesuai dengan apa yang diminta. Hal ini terlihat dari hasil wawancara dengan siswa ASD, bahwa siswa tersebut sering mengecek hasil jawabannya. Tahap Advanced clarification, bahwa siswa ASD dengan multiple intelligences tinggi sekali dapat mendefinisikan hasil jawaban yang dikerjakan yaitu dengan istilah dan mempertimbangkan hasil akhir sebagai asumsinya (Nurfitriyanti et. al., 2020). Tahap akhir yaitu Supposition and integration, siswa ASD dapat mempertimbangkan alasan atau asumsi-asumsi jawaban yang diragukan. ASD menggabungkan kemampuan dan karakter berpikirnya dalam menentuan keputusan jawabannya. Oleh karena itu sangat penting dalam melihat karakteristik siswa dalam pembelajaran (Agoestanto \& Sukestiyarno, 2017; Apriliani \& Suyitno, 2016; Suyitno et. al., 2016)

Hasil justifikasi menujukkan bahwa siswa mampu mengidentifikasi masalah, menjelaskan, menggunakan bukti-bukti yang benar, menarik kesimpulan, member penjelasan lanjut, dan mampu memadukan suatu keputusan dalam pemecahan masalah matematika. Sehingga siswa dengan multiple intelligences tinggi sekali yaitu sangat kritis dalam menyelesaikan masalah, atau dengan pola kategori pada tingkat 4.

Pada tahap elementary clarification, NR fokus dalam mengidentifikasi pertanyaan yaitu mengulas soalnya untuk dipahami. Kemudian mencari informasi dari soal terhadap informasi apa yang belum dipahami. Namun NR faham terhadap soal, baik penjumlahan dan pengurangan aljabar. Selain itu, siswa NR dapat dengan mudah mengidentifikasi jawaban yang mungkin akan didapatnya. Selanjutnya mengidentifikasi kesimpulan dari masalah yang telah diberikan. Pada tahap basis for the decision,subjek NR dapat menerka langkah-langkah terhadap soal nomor 1 tentang penjumlahan dan nomor 2 tentang pengurangan. Asumsinya bahwa langkah-langkah tersebut akan digunakan untuk menyelesaikan masalah. Tahapan Inference, subjek NR melakukan pertimbangaan terhadap jawaban yang akan didapat, yaitu mengelompokkan 1 suku pada persamaan dua variabel tersebut. Kemudian pada tahapan Advanced clarification, subjek NR melakukan identifikasi terhadap hasil yang telah dilakukan. Selanjutnya adalah Supposition and integration, subjek NR melakukan dugaan terhadap jawaban dengan mengecek kembali, sesuai dengan anggapan bahwa soal telah selesai dan benar dikerjakan. Subjek NR melakukan justifikasi terhadap masalah dari soal dan yang ditanyakan dan tehadap langkah-langkah digunakan. Dampaknya bahwa NR menemukan jawaban dengan benar. Siswa mampu mengidentifikasi masalah, menjelaskan, menggunakan bukti-bukti yang benar, menarik kesimpulan, memberi penjelasan lanjut dan kurang mampu 
memadukan membuat suatu keputusan dalam pemecahan masalah matematika (Komarudin et. al., 2021). Sehingga siswa dengan multiple intelligences tinggi yaitu kritis dalam menyelesaikann masalah, atau dengan pola kategori pada tingkat 3.

Pada tahap elementary clarification, siswa DCM fokus pada pertanyaan yang diberikan oleh peneliti, selain itu siswa dapat mengidentifikasi pertanyaan atau masalah yang ada. Siswa dapat mengidentifikasi jawaban yang mungkin akan didapatnya. Kemudian siswa dapat mengidentifikasi kesimpulan dari masalah yang telah diberikan. Terlihat bahwa soal yang diberikan terkait dengan penjumlahan dan pengurangan bentuk aljabar (Syamsul et. al., 2020; Widyastuti et. al., 2021).

Pada tahap basis for the decision, bahwa siswa dapat menerka jawaban dari apa yang telah meraka pelajari sebagai materi prasyarat, yaitu penjumlahan dan pengurangan. Kemudian siswamulai mengamati soal dan langkah-langkah yang telah dikerjakannya untuk merencanakan hasil yang didapat. Namun pada soal kedua salah dalam mengelompokkan suku, sehingga membentuk operasi perkalian. Tahap Inference, siswa dapat mempertimbangkan capaian hasilnya, mempertimbangkan apakah hasil jawaban tersebut telah sesuai dengan apa yang diminta. Namun di sisi lain, DCM melakukan pertimbangaan terhadap jawaban yang akan didapat, yaitu 1 suku pada persamaan dua variabel. Soal pertama telah benar dilakukan langkahnya. Tahap Advanced clarification, bahwa siswa DCM dengan multiple intlligences cukup dapat mendefinisikan hasil jawaban yang dikerjakan dan mempertimbangkan hasil akhir sebagai asumsinya. Namun terkadang masih salah dengan langkah pengerjaannya. Tahap akhir yaitu Supposition and integration, siswa DCM dapat mempertimbangkan alasan atau asumsi-asumsi jawaban yang diragukan. DCM dapat mengecek kembali bahwa soal yang telah dikerjakan adalah telah selesai dan benar. Sehingga DCM dapat menjustifikasi soal dan jawabannya, namun masih salah dalam langkahnya. Siswa mampu mengidentifikasi masalah, menjelaskan, menggunakan bukti-bukti yang benar, menarik suatu kesimpulan, belum mampu memberi penjelasan dan belum mampu memadukan membuat suatu keputusan dalam pemecahan masalah matematika (Suherman, Vidákovich, et. al., 2021). Sehingga siswa dengan multiple intelligences cukup yaitu cukup kritis dalam menyelesaikann masalah, atau dengan pola kategori pada tingkat 2 .

Pada tahap elementary clarification, siswa GA fokus dalam mengidentifikasi masalah. Selain itu, siswa mulai sedikit mengidentifikasi jawaban yang mungkin akan didapatnya. Namun terkadang tidak yakin terhadap identifikasinya. Siswa GA dapat mengidentifikasi kesimpulan dari masalah yang telah diberikan. Terlihat bahwa soal yang diberikan terkait dengan penjumlahan dan pengurangan bentuk aljabar. Pada tahap basis for the decision, bahwa siswa dapat mempertimbangkan jawaban dari apa yang telah meraka pelajari sebagai materi prasyarat, yaitu penjumlahan dan pengurangan. Kemudian siswa mulai mengamati soal dan langkah-langkah yang telah dikerjakannya untuk merencanakan hasil yang didapat. Didapat data bahwa langkah-langkah yang digunakan subjek GA adalah pertama menuliskan soal yang ditanyakan. Setelah itu menggabungkan suku kedua dengan mengurangkan mengurangkan dengan suku pertamanya berdasarkan soal yang didapat dengan cara memberi tanda kurung siku. Kemudian membuka kurung siku namun tidak menambahkan operasi, sehingga yang didapat adalah bentuk perkalian. Hal tersebut dilakukan oleh subjek GA pada soal $a$ dan $b$. Tahap Inference, siswa dapat mempertimbangkan capaian hasilnya, tetapi tidak melakukan dugaan dan pertimbangaan terhadap jawaban yang akan didapat. Sehingga dengan langkah kedua yang salah, yaitu berbentuk perkalian, tetapi hasil akhir yang didapat adalah benar dengan menjumlahkannya masing-masing variabelnya dan konstantanya.

Tahap Advanced clarification, bahwa siswa GA tidak melakukan cek terhadap hasil yang telah dilakukan. Dan kemudian tahap akhir yaitu Supposition and integration, subjek GA melakukan dugaan yang salah tehadap langkah-langkah, hal ini disamakan dengan langkah pada no.1, namun salah dalam mengintegrasikan langkah kedua, tetapi hasil akhir benar.

Pada tahap elementary clarification, subjek LS belum fokus dalam mengidentifikasi pertanyaan. Sehingga terkadang ragu dengan soal yang diberikan yaitu penjumlahan dan pengurangan bentuk aljabar. 
Pada soal kedua, LS tidak mengidentifikasi pertanyaan, yang mengakibatkan salah dalam penulisan ulang soalnya. Pada tahap basis for the decision, subjek LS belum menerka langkah-langkah yang akan digunakan untuk memecahkan masalah. Selain itu, subjek LS tidak menduga langkah-langkah seperti pengurangan. Ditambah lagi salah dalam menuliskan soal dan variabel. Berdasarkan pengerjaan, LS menuliskan variabel $d$, hal ini tidak diketahui dalam soal, yang mengakibatkan salah dalam penulisa, pengoperasian, dan hasilnya. Tahap Inference, subjek LS tidak melakukan dugaan dan pertimbangaan terhadap jawaban yang akan didapat. Sehingga salah dalam hasilnya. Seperti pada hasil soal nomor 2. Tahap Advanced clarification, subjek LS tidak mengecek soal dan jawaban yang telah ditulisnya. Yang mengakibatkan kesalahn penulisan dan hasil soal.Tahap akhir yaitu Supposition and integration, subjek LS melakukan dugaan yang salah tehadap langkah-langkahnya, sehingga penulisan dan hasil yang tidak benar. Hasil justifikasi yaitu LS tidak melakukan justifikasi terhadap langkah dan jawaban soal, yang mengakibatkan salah langkah penyelesaian dan hasil akhirnya. Hal ini bahwa sswa tidak mampu mengidentifikasi masalah, memberi penjelasan, menggunakan bukti-bukti yang benar, menarik suatu kesimpulan, dan tidak mampu memadukan membuat suatu keputusan dalam pemecahan masalah matematika (Rahmadani et. al., 2021; Suhartono et. al., 2021; Suherman, Zaman, et. al., 2021). Sehingga siswa dengan multiple intelligences rendah tidak kritis dalam menyelesaikann masalah, atau dengan pola kategori pada tingkat 0 .

\section{SIMPULAN}

Berdasarkan hasil analisis, dapat disimpulkan bahwa siswa dapat mengidentifikasi langkah pengerjaan soal kemampuan berpikir kritis matematis. Sehingga lebih kritis dalam menyelesaikan masalah, dan terlihat benar dalam pengerjaan soalnya. Siswa mengarahkan jawaban dimulai dari hal yang bersifat khusus kemudian secara umum. Pola berpikir kritis matematis cenderung dengan pola induktif. Adapun pola berpikir kritis matematis siswa dengan multiple intelligences Interpersonal yaitu sangat kritis dalam menyelesaikann masalah, atau dengan pola kategori pada tingkat 4. Siswa dengan multiple intelligences musical yaitu kritis dalam menyelesaikann masalah, atau dengan pola kategori pada tingkat 3 . Sedangkan siswa dengan multiple intelligences linguistic yaitu cukup kritis dalam menyelesaikann masalah, atau dengan pola kategori pada tingkat 2. Selanjutnya bahwa siswa dengan multiple intelligences kinethetic thetic yaitu kurang kritis dalam menyelesaikann masalah, atau dengan pola kategori pada tingkat 1 . Siswa dengan multiple intelligences spasial yaitu tidak kritis dalam menyelesaikann masalah, atau dengan pola kategori pada tingkat 0 .

Penelitian ini hanya berfokus pada pola karakteristik multiple intelligences siswa terhadap berpikir kritis matematis. Sehingga dapat dijadikan acuan untuk menggolongkan siswa dalam proses pembelajaran matematika.

\section{UCAPAN TERIMA KASIH}

Ucapan terima kasih kepada SMPN 29 Bandar Lampung atas data penelitian. Selain itu, Universitas Islam Negeri Raden Intan Lampung atas support-nya dan Universitas Negeri Semarang untuk program penyelesaian disertasi program Doktor.

\section{DAFTAR RUJUKAN}

Agoestanto, A., \& Sukestiyarno, Y. L. (2017). Analysis of mathematics critical thinking students in junior high school based on cognitive style. Journal of Physics: Conference Series, 824(1), 012052. Retrieved from: https://iopscience.iop.org/article/10.1088/1742-6596/824/1/012052 
Anisa, A. (2017). Meningkatkan keterampilan berpikir kritis peserta didik melalui pembelajaran IPA berbasis potensi lokal Jepara. Jurnal Inovasi Pendidikan IPA, 3(1), 1-11. https://doi.org/10.21831/jipi.v3i1.8607

Apriliani, L. R., \& Suyitno, H. (2016). Kemampuan berpikir kreatif matematis berdasarkan kecemasan matematika pada pembelajaran creative problem solving berteknik SCAMPER. Unnes Journal of Mathematics Education Research, 5(2), 131-138.

Barnhart, T., \& van Es, E. (2015). Studying teacher noticing: Examining the relationship among pre-service science teachers' ability to attend, analyze and respond to student thinking. Teaching and Teacher Education, 45, 83-93. https://doi.org/10.1016/j.tate.2014.09.005

Fuad, N. M., Zubaidah, S., Mahanal, S., \& Suarsini, E. (2017). Improving Junior High Schools' Critical Thinking Skills Based on Test Three Different Models of Learning. International Journal of Instruction, 10(1), 101-116. https://doi.org/10.12973/iji.2017.1017a

Glazzard, J. (2015). A critical analysis of learning styles and multiple intelligences and their contribution to inclusive education. Journal of Global Research in Education and Social Science, 2(3), 107-113. Retrieved from: https://eprints.leedsbeckett.ac.uk/id/eprint/3999/

Hamidah, K., \& Suherman, S. (2016). Proses Berpikir Matematis Siswa dalam Menyelesaikan Masalah Matematika ditinjau dari Tipe Kepribadian Keirsey. Al-Jabar: Jurnal Pendidikan Matematika, 7(2), 231-248. https://doi.org/10.24042/ajpm.v7i2.38

Hand, B., Shelley, M. C., Laugerman, M., Fostvedt, L., \& Therrien, W. (2018). Improving critical thinking growth for disadvantaged groups within elementary school science: A randomized controlled trial using the Science Writing Heuristic approach. Science Education, 102(4), 693-710. https://doi.org/10.1002/sce.21341

Hartinah, S., Suherman, S., Syazali, M., Efendi, H., Junaidi, R., Jermsittiparsert, K., \& Umam, R. (2019). Probing-prompting based on ethnomathematics learning model: The effect on mathematical communication skill. Journal for the Education of Gifted Young Scientists, 7(4), 799-814. https://doi.org/10.17478/jegys.574275

Huda, S., Rinaldi, A., Suherman, S., Sugiharta, I., Astuti, D. W., Fatimah, O., \& Prasetiyo, A. E. (2019). Understanding of Mathematical Concepts in the Linear Equation with Two Variables: Impact of ELearning and Blended Learning Using Google Classroom. Al-Jabar: Jurnal Pendidikan Matematika, 10(2), 261-270. https://doi.org/10.24042/ajpm.v10i2.5303

Komarudin, K., Suherman, S., \& Anggraini, A. (2021). Analysis of Mathematical Concept Understanding Capabilities: The Impact of Makerspae STEM Learning Approach Models and Student Learning Activities. Journal of Innovation in Educational and Cultural Research, 2(1), 35-43.

Komarudin, Pranata, D., Nurhasanah, U., \& Suherman. (2020). Developing Islamic-Friendly Android Mobile Apps for Understanding Mathematical Concepts. 1st Raden Intan International Conference on Muslim Societies and Social Sciences (RIICMuSSS 2019), 110-117.

Mahanal, S., Zubaidah, S., Sumiati, I. D., Sari, T. M., \& Ismirawati, N. (2019). RICOSRE: A Learning Model to Develop Critical Thinking Skills for Students with Different Academic Abilities. International Journal of Instruction, 12(2), 417-434.

Matondang, K., Hasratuddin, H., \& Armanto, D. (2020). Pengembangan Model Pembelajaran RME Berbantuan ICT untuk Meningkatkan Kemampuan Komunikasi dan Berpikir Kritis Matematis Siswa. Edumaspul: Jurnal Pendidikan, 4(1), 22I8-241.

Miles, M. B., Huberman, A. M., \& Saldaña, J. (2018). Qualitative data analysis: A methods sourcebook. Sage publications.

Mujib, M. (2019). Penjenjangan Kemampuan Berpikir Kritis Matematis Berdasarkan Teori Bloom Ditinjau Dari Kecerdasan Multiple Intelligences. Desimal: Jurnal Matematika, 2(1), 87-103. 
Mujib, M., \& Mardiyah, M. (2017). Kemampuan Berpikir Kritis Matematis Berdasarkan Kecerdasan Multiple Intelligences. Al-Jabar: Jurnal Pendidikan Matematika, 8(2), 187-196.

Nugraha, A. J., Suyitno, H., \& Susilaningsih, E. (2017). Analisis kemampuan berpikir kritis ditinjau dari keterampilan proses sains dan motivasi belajar melalui model pbl. Journal of Primary Education, $6(1), 35-43$.

Nurfitriyanti, M., Rosa, N.M., \& Nursa'adah, F.P. (2020). Pengaruh Kemampuan Berpikir Kritis, Adversity Quotient dan Locus of Control terhadap Prestasi Belajar Matematika. JKPM (Jurnal Kajian Pendidikan Matematika), 5(2), 263-272.

Perveen, A. (2018). Facilitating multiple intelligences through multimodal learning analytics. Turkish Online Journal of Distance Education, 19(1), 18-30.

Rahmadani, N. A., Vidákovich, T., Fitria, N., Putri, N. I. S., Addarojat, M. R., \& Priadi, M. (2021). SQ3R method assisted by ethnomathematics-oriented student worksheet: The impact of mathematical concepts understanding. Journal of Physics: Conference Series, 1796(1), 012059.

Sener, S., \& Çokçaliskan, A. (2018). An investigation between multiple intelligences and learning styles. Journal of Education and Training Studies, 6(2), 125-132.

Setiawan, R., \& Mardapi, D. (2020). Multiple Intelligences-Based Creative Curriculum: The Best Practice. European Journal of Educational Research, 9(2), 611-627.

Setyawati, D. U. (2020). Profil Kemampuan Berpikir Kritis Mahasiswa dalam Menyelesaikan Soal Pemecahan Masalah Matematika Ditinjau dari Jenis Kelamin. Jurnal Didaktik Matematika, 7(1), 90-104.

Sitorus, J. (2016). Students' creative thinking process stages: Implementation of realistic mathematics education. Thinking Skills and Creativity, 22, 111-120.

Suhartono, S., Lumamuly, P. C., Sahertian, N. L., Joseph, L. S., Aralaha, R., \& Yowelna Tarumasely, S. (2021). A Theoretical Study: The Flipped Classroom Model As An Effective And Meaningful Learning Model In Multiple Era. Psychology and Education Journal, 58(1), 4811-4820.

Suherman, S. (2013). PROSES BERNALAR SISWA DALAM MENGERJAKAN SOAL-SOAL OPERASI BILANGAN DENGAN SOAL MATEMATIKA REALISTIK. JIPM (Jurnal Ilmiah Pendidikan Matematika), 1(2).

Suherman, S., Vidákovich, T., \& Komarudin, K. (2021). STEM-E: Fostering mathematical creative thinking ability in the 21st Century. Journal of Physics: Conference Series, 1882(1), 012164.

Suherman, S., Zaman, A. M., \& Farida, F. (2021). Fostering of Mathematical Critical Thinking Ability Using ARCS Model and Students' Motivation. JTAM (Jurnal Teori Dan Aplikasi Matematika), 5(1), 134-143.

Sulistiani, E., \& Masrukan, M. (2017). Pentingnya berpikir kritis dalam pembelajaran matematika untuk menghadapi tantangan MEA. PRISMA, Prosiding Seminar Nasional Matematika, 605-612.

Suyitno, A., Sugiharti, E., \& Pujiastuti, E. (2016). Build Of Effective Training Model Based On The Searching Toward Competence Of Teachers In Mathematics Teaching. International Journal of Education and Research Vol. 4 No. 11 November.

Syamsul, H., Suherman, S., Komarudin, K., Muhamad, S., \& Rofiqul, U. (2020). The Effectiveness of AlQurun Teaching Model (ATM) Viewed from Gender Differences: The Impact on Mathematical Problem-Solving Ability. IOP Conf. Series: Journal of Physics, 1467, 1-8.

Widyastuti, R., Retnosari, T. D., \& Mudrikah, I. (2021). Construct 2 learning media developments to improve understanding skills. Journal of Physics: Conference Series, 1796(1), 012051.

Zubaidah, S., Fuad, N. M., Mahanal, S., \& Suarsini, E. (2017). Improving creative thinking skills of students through differentiated science inquiry integrated with mind map. Journal of Turkish Science Education, 14(4), 77-91. 